\title{
Implementasi Pendidikan Berbasis Fitrah Manusia dalam Penanaman Nilai Agama dan Moral pada Anak Usia Dini di Tk Islam El-Qalam Pamulang
}

\author{
Nurhakimah' ${ }^{1}$ Ahmad Dimyati², Syahida Rena ${ }^{3}$ \\ 1,2,3 Institut Ilmu Al-Qur'an (IIQ) Jakarta, Indonesia \\ E-mail: jatzanoor@gmail.com,achmad.dimyati@iiq.ac.id,syahidah.rena@iiq.ac.id
}

\begin{tabular}{l}
\hline Article Info \\
\hline Article History \\
Received: $2021-12-27$ \\
Revised: 2022-01-22 \\
Published: 2022-02-03
\end{tabular}

Keywords: Implementation; Fitrah;

Religious Values;

Moral;

Early childhood.

\begin{abstract}
This research is motivated by low religious and moral values, the lack of children's ability to speak well and behave politely in early childhood and education that is not in accordance with their nature in the El-Qalam Islamic Kindergarten. The formulation of the problem from this research is how to implement human nature education in inculcating Islamic religious and moral values in early childhood and how the suitability of human nature education in inculcating Islamic religious and moral values in early childhood in El-Qalam Pamulang Kindergarten. The purpose of this study is to answer the formulation of the problem and research. The research method used is a qualitative approach. Data was collected using observation, questionnaires, interviews, and documentation studies. The results of this study indicate that the implementation of religious and moral values in El-Qalam Pamulang Islamic Kindergarten students has been carried out in every activity from the beginning of learning. The core learning until the end of the lesson is carried out using the method of exemplary, habituation, repetition, training and motivation.
\end{abstract}

\begin{tabular}{l}
\hline Artikel Info \\
\hline Sejarah Artikel \\
Diterima: 2021-12-27 \\
Direvisi: $2022-01-22$ \\
Dipublikasi: $2022-02-03$
\end{tabular}

Kata kunci: Implementasi; Fitrah; Nilai Agama; Moral; Anak Usia Dini.

\section{PENDAHULUAN}

Allah SWT menciptakan manusia sebagai makhluk yang paling sempurna yang dianugerahi berbagai kelebihan. Manusia di dalam dirinya menurut (Arifudin, 2020) bahwa memiliki struktur yang terdiri dari jasmaniah dan rohaniah atau fisiologis dan psikologis. Anatomi tubuhnya tersusun dengan baik dan seimbang dibanding dengan makhluk Allah yang lain. Manusia dianugerahi Allah akal pikiran yang digunakan untuk mengenal Allah, memahami alam semesta, menjadi instrumen untuk belajar, dan berpikir agar manusia mempunyai peradaban. Selain itu manusia diberikan Allah kehendak bebas yang dapat menentukan dan memilih mana yang baik dan mana buruk, halal dan haram, pantas dan tidak pantas, serta boleh tidak boleh yang menjadikan manusia menjadi taat atau ingkat kepada Allah SWT.

Manusia juga dijadikan oleh Allah pemimpin atau khalifah di muka bumi yang diberikan kewenangan mengatur bumi agar bermanfaat untuk makhluk Allah yang lain (Supriani, 2022). Maka Allah berikan manusia kompetensi bawaan untuk mengembangkan diri dan membuat kemajuan-kemajuan dalam kehidupannya agar dapat hidup lebih nyaman, dalam ajaran Islam kompetensi bawaan ini dapat dinamakan sebagai fitrah. Allah SWT telah menyatakan dalam AlQuran tentang fitrah ini dalam surat Ar-Rum ayat 30 yang artinya: "Maka hadapkanlah wajahmu dengan lurus kepada agama Allah" (tetaplah atas) fitrah Allah yang telah menciptakan manusia menurut fitrah itu, tidak ada perubahan 
pada fitrah Allah. (Itulah) agama yang lurus; tetapi kebanyakan manusia tidak mengetahui" (QS.Ar-Rum[30]:30). Kata fitrah ini juga disebutkan dalam hadits yang diriwayatkan oleh Abu Hurairah yang artinya: "Abdan Menceritakan kepada kami (dengan berkata) Abdullah memberitahukan kepada kami (yang berasal) dari al-Zukhri (yang menyatakan) Abu salamah bin Abd al-Rahman memberitahukan kepadaku bahwa Abu Hurairah berkata: Rasulullah SAW bersabda "setiap anak lahir (dalam keadaan) Fitrah, kedua orang tuanya (memiliki andil dalam) menjadikan anak beragama Yahudi, Nasrani, atau bahkan beragama Majusi, sebagaimana binatang ternak memperanakkan seekor binatang (yang sempurna anggota tubuhnya). Apakah anda melihat anak binatang itu ada yang cacat (putus telinganya atau anggota tubuhnya yang lain) kemudian beliau membaca, (tetaplah atas) fitrah Allah yang telah menciptkan menurut manusia fitrah (HR. Muslim), dalam mengembangkan komptensinya sesuai fitrah, manusia mengalami proses pendidikan (Na'im, 2021). Proses pendidikan pada manusia tidak terlepas dari pemikiran imam Al-Ghazali bahwa pendidikan tidak akan terjadi jika tidak bermula dari fitrah manusia.

Ibnu Miskawih, menambahkan satu unsur lagi disamping unsur jasad dan jiwa, yaitu unsur hayah (unsur hidup), hal ini karena pada diri manusia ketika dalam bentuk embrio (perpaduan antara ovum dan sperma) sudah terdapat kehidupan walaupun roh belum ditiupkan, sedangkan hayah sendiri terdapat pada sperma dan ovum yang membuat embrio hidup dan berkembang, jadi hayah bukan komponen jasmani yang berasal dari tanah dan bukan pula komponen jiwa atau rohani yang ditiupkan oleh Allah. Berdasarkan teori-teori tersebut di atas dapat dijelaskan bahwa terdapat tiga kategori penggolongan manusia diantaranya yaitu sebagai berikut:

1. Sebagai makhluk biologis yang memiliki perbedaan dengan lainnya karena fisik manusia memiliki kesempurnaan.

2. Manusia sebagai makhluk psikis yang memiliki potensi rohani yang menempatkan manusia sebagai makhluk yang bermartabat tinggi, yang memiliki perbedaan dengan makhluk lainnya. Hal ini berarti bahwa jika potensi psikis tidak dimanfaatkan maka dapat lebih hina dari makhluk lainnya.

3. Manusia sebagai mahluk sosial yang memiliki tugas khalifah terhadap alam semesta, yang mempunyai tanggung jawab untuk mengelola alam semesta demi kemakmuran, keselamatan dan kebahagiaan bersama dengan makhluk lain.

\section{METODE PENELITIAN}

Penelitian ini berusaha untuk menganalisis dan mendeskripsikan implementasi pendidikan berbasis fitrah manusia dalam penanaman nilai agama dan moral pada anak usia dini di TK Islam El-Qalam Pamulang, adapun pendekatan yang digunakan dalam penelitian ini adalah pendekatan kualitatif. Menurut Bogdan dan Taylor dalam (Bahri, 2021) menyatakan pendekatan kualitatif adalah prosedur penelitian yang menghasilkan data deskriptif berupa kata-kata tertulis atau lisan dari orang-orang dan perilaku yang dapat diamati, caranya dengan mentranskripsikan data, kemudian pengkodean pada catatan-catatan yang ada dilapangan dan diinterpretasikan data tersebut untuk memperoleh kesimpulan. Jenis penelitian yang digunakan pada penelitian ini adalah berupa studi deskriptif, menurut (Rahayu, 2020) bahwa studi deskriptif adalah penelaahan secara empiris yang menyelidiki suatu gejala dalam latar kehidupan nyata kemudian menggambarkan penelitiannya dengan permasalahanpermasalahan yang ada, hasil penelitian ini dikumpulkan dengan data primer dan data skunder. Penentuan teknik pengumpulan data yang tepat sangat menentukan kebenaran ilmiah suatu penelitian, teknik pengumpulan data yang digunakan dalam penelitian ini adalah:

\section{Observasi}

Secara umum bahwa observasi yakni terkait dengan pengamatan secara langsung dengan sistematis terhadap gejala-gejala yang hendak diteliti di lapangan (Arifudin, 2018). Dengan metode ini, peneliti dapat melihat dan merasakan secara langsung suasana dan kondisi subyek penelitian. Hal-hal yang diamati dalam penelitian ini adalah tentang implementasi pendidikan berbasis fitrah manusia dalam penanaman nilai agama dan moral pada anak usia dini Di Tk Islam ElQalam Pamulang.

Tabel 1. Pedoman Observasi Implementasi Pendidikan Berbasis Fitrah Manusia

\begin{tabular}{lll}
\hline No & Indikator & Hasil Observasi \\
\hline 1 & Nilai Tauhid & $\begin{array}{l}\text { Sudah } \\
\text { terimplementasikan }\end{array}$ \\
\hline 2 & Niali Jujur & $\begin{array}{l}\text { Sudah } \\
\text { terimplementasikan }\end{array}$ \\
\hline 3 & Nilai Sabar & $\begin{array}{l}\text { Sudah } \\
\text { terimplementasikan }\end{array}$ \\
\hline 4 & $\begin{array}{l}\text { Nilai Tanggung } \\
\text { Jawab }\end{array}$ & $\begin{array}{l}\text { Sudah } \\
\text { terimplementasikan }\end{array}$ \\
\hline
\end{tabular}




\begin{tabular}{ccl}
\hline 5 & Nilai Sopan & $\begin{array}{l}\text { Sudah } \\
\text { terimplementasikan }\end{array}$ \\
\hline 6 & Nilai Menghargai & $\begin{array}{l}\text { Sudah } \\
\text { terimplementasikan }\end{array}$ \\
\hline 7 & Nilai Peduli & $\begin{array}{l}\text { Sudah } \\
\text { terimplementasikan }\end{array}$ \\
\hline
\end{tabular}

2. Wawancara

Teknik wawancara dalam penelitian ini adalah wawancara terstruktur yaitu wawancara yang dilakukan dengan meng-gunakan pedoman yang telah ditetapkan sebelumnya, pertanyaan disusun secara ketat dan pertanyaan sama pada setiap subjek sesuai dengan tujuan dari penelitian (Ulfah, 2022).

\section{Dokumentasi}

Dokumentasi adalah salah satu teknik pengumpulan data melalui dokumen atau catatan-catatan tertulis yang ada (Tanjung, 2022), dokumentasi berasal dari kata dokumen, yang berarti barang-barang tertulis., didalam melaksanakan metode dokumentasi, peneliti menyelidiki benda-benda tertulis, seperti buku-buku, majalah, notula rapat, dan catatan harian. Menurut Moleong dalam (Nasser, 2021) bahwa metode dokumentasi adalah cara pengumpulan informasi atau data-data melalui pengujian arsip dan dokumen-dokumen, strategi dokumentasi juga merupakan teknik pengumpulan data yang diajukan kepada subyek penelitian. Metode pengumpulan data dengan menggunakan metode dokumentasi ini dilakukan untuk mendapatkan data tentang keadaan lembaga (obyek penelitian) yaitu keberadaan lembaga, keadaan Kepala Sekolah dan keadaan guru-gurunya.

\section{HASIL DAN PEMBAHASAN}

Pada deskripsi subjek penelitian ini Peneliti melakukan wawancara, dan observasi serta mengambil dokumentasi untuk mengetahui bagaimana implementasi pendidikan berbasis Fitrah dalam penanaman nilai agama dan moral pada anak usia dini di TK Islam El-Qalam. Kepala Sekolah TK Islam El-Qalam adalah sumber utama informasi yang akan diperoleh oleh peneliti. Pada gambaran umum TK Islam El-Qalam ini akan menjelaskan bagaimana kondisi TK Islam ElQalam yaitu dengan beberapa penjelasan sebagai berikut:

1. Letak geografis.

2. Sejarah dan latar belakang berdirinya TK Islam El-Qalam.

3. Tujuan Pendidikan TK Islam El-Qalam.
4. Visi, misi Taman Kanak-kanak (TK) Islam ElQalam.

5. Kurikulum TK Islam El-Qalam Pamulang.

6. Program Unggulan.

7. Keadaan Pendidik dan peserta Didik.

Untuk mengetahui implementasi nilai fitrah manusia yang tertuang dalam pengembangan nilai agama moral pada anak usia dini di TK Islam El-Qalam Pamulang tahun pelajaran 2019/2020, peneliti mengadakan wawancara pada tanggal 04 November 2019 kepada Kepala TK Islam El-Qalam bagaimana memajukan TK Islam El-Qalam. Beliau menjelaskan bahwa imlementasi pendidikan berbasis pendidikan fitrah manusia tertuang dalam pendidikan dan penanaman nilai agama moral dilakukan setiap hari, pada setiap pembelajaran atau kegiatan peserta didik dilakukan pembiasaan-pembiasaan yang mebentuk karakter baik pada anak. Keteladanan seorang pendidik juga sangat efektif dalam pembelajaran, TK Islam El-Qalam Pamulang menerapkan pembelajaran yang mengutamakan keteladanan berulang-ulang dan terus menerus. Hal ini diterapkan karena pembelajaran pada anak usia dini haruslah melihat dan mendengar secara langsung, dan harus berulang-ulang dan terus menerus hingga menjadi sebuah pembiasaaan yang baik yang melekat pada anak.

Pada wawancara peneliti kepada kepala TK Islam El-Qalam juga menjelaskan bahwa setiap kegiatan dalam penanaman nilai Agama dan Moral sudah masuk kedalam Rencana Persiapan Pembelajaran Harian (RPPH) dan Rencana Persiapan Pembelajaran Mingguan (RPPM) dan rencana Persiapan pembelajaran Semester (RPPS) dan tertuang dalam Standar Tingkat Pencapaian Perkembangan Anak (STPPA).

1. Implementasi Nilai Agama di TK Islam ElQalam Pamulang

Penanaman nilai agama pada TK Islam ElQalam sangat ditekankan pada peserta didik TK Islam El-Qalam, hal ini menjadi ciri khas pendidikan anak usia dini di sekolah tersebut, ada beberapa nilai agama di TK El-Qalam yang peneliti temui, yaitu diantaranya adalah tauhid, Jujur, sabar dan tanggung jawab.

a) Implementasi Nilai Tauhid

Salah satu nilai agama yang ditanamkan pada peserta didik El-Qalam adalah pengenaan terhadap Tuhannya yaitu Allah SWT. Penanaman aqidah bahwa tidak ada Tuhan Selain Allah SWT, tidak ada tuhan yang berhak disembah selain Allah SWT. Mendidik dengan mengenalkan dan men- 
cintai Allah, yang menciptakannya dan seluruh alam semesta, mengenal dan mencintai Rasulullah SAW, yang pada diri beliau terdapat suri tauladan yang mulia serta agar mereka mengenl dan memahami islam untuk diamalkan. Ajarkan Tauhid, yaitu bagaimana mentauhidkan Allah, dan jauhkan serta laranglah anak dari berbuat syirik. Pada penanaman tauhid ini peneliti mendapatkan beberapa penemuan dalam observasi dan wawancara dengan penjelasan dari Kepala Sekolah TK Islam El-Qalam Pamulang, penanaman tauhid pada anak selalu dilakukan setiap hari yaitu diantaranya dengan kegiatan doa diawal dan diakhit kegiatan, dengan berdoa guru kelas menjelaskan bahwa kita sedang meminta kepada Tuhan yaitu Allah SWT. Pada awal kegiatan anak berbaris dan membaca doa, surat-surat pendek dan hadits-hadits Rosulullah SAW.

Pembelajaran nilai agama pada ketauhidan untuk anak dilakukan setiap waktu dan sebenarnya ada target tersendiri dan target tersebut tidak ditulis. Seperti setiap hari itu berdo'a, sholat dhuha bersama setiap hari jumat, anakanak diajarkan tata cara sholat, bacaan sholat, dzikir setelah sholat. Anank-anak juga diajarkan tata cara berwudlu sebelum sholat, anak-anak berbaris mengantri untuk menunggu giliran. Shalat merupakan perintah langsung dari Allah SWT kepada ummat Muslim dan hukumnya wajib pada 5 waktu, yaitu shalat subuh, zuhur, ashar, maghrib dan isya. Seorang anak belum diwajibkan untuk melaksanakan shalat sebagaimana yang diwajibkan atas muslim yang telah baligh. Namun sebagai lembaga pendidikan yang berciri khas Agama Islam TK Islam El-Qalam mengajak peserta didiknya untuk melaksanakan shalat sebagai pengenalan dan pembiasaan merupakan sebuah kewajiban.

b) Implementasi Nilai Jujur

Penanaman karakter kejujuran di TK Islam El-Qalam Pamulang sangat penting untuk dikembangkan, setiap manusia dalam rangka membentuk karakter pada anak usia dini yaitu dengan cara memberikan model untuk hal-hal yang positif, kami selalu menerapakan dengan kedisiplinan, setiap hari, anak-anak mengungkapkan keadaannya saat datang bertemu dengan guru pada pagi hari, dan kami juga ada cerita-cerita atau kisah-kisah keteladanan tentang kejujuran. Pernyataan Ibu Kepala Sekolah tersebut diatas juga dikuatkan oleh guru dikelompok B1 bahwasanya anak dilatih jujur dengan mendisplinkan anak-anak sejak usia dini. Karena disiplin bisa menumbuhkan sikap jujur pada anak.

c) Implementasi Nilai Sabar

Karakter selanjutnya yang ditananmkan pada peserta didik TK Islam El-Qalam adalah karakter sabar, penanaman sikap tidak sekedar memberi pengetahuan baik dan buruk tetapi lebih pada menumbuhkan kesadaran dan menerapkan akan nilai baik dan buruk dalam perilaku sehari-hari. Oleh karena itu penanaman sikap harus dilakukan secara lembut dan menyenangkan. Suasana dan lingkungan yang aman dan nyaman, perlu diciptakan dalam proses penanaman nilai-nilai sikap, untuk memperdalam pemahaman sikap yang diharapkan, setiap nilai sikap yang telah dimasukan ke dalam rencana pembelajaran harus diterapkan secara ber-kelanjutan. Penanaman nilai sikap terus diterapkan dalam bentuk pembiasaan yang direncanakan secara matang oleh satuan PAUD, sikap yang diterapkan dimasukkan dalam RPPH atau dalam SOP. Pada nilai agama tentang karakter sabar pada anank usia dini di TK Islam El-Qalam peneliti melakukan observasi dan wawancara pada beberapa kelas, peneliti mewawancarai juga kepala TK Islam El-Qalam Pamulang, karena pendidikan yang baik juga bergantung pada pengelolaan yang baik. Menurut Kepala Sekolah, metode setiap pembelajara di TK Islam El-Qalam yaitu keteladanan, pembiasaan dan berulangulang atau mudawwamah.

d) Implementasi Nilai Tanggung Jawab

Dalam bermain dan belajar pada peserta didik TK Islam El-Qalam Pamulang sudah ditanamkan belajar rasa tanggung jawab, tanggung jawab ini harus sudah ditanamkan pada setiap anak sejak usia dini. Guru-guru pada pendidikan anak usia dini di TK Islam El-Qalam Pamuilang berusaha keras untuk menanamkan tanggung jawab kepada seeluruh anak. Hal ini dapat dilakukan dengan berbagai cara pada setiap kegiatan yang dilakukan anak disekolah. Contohnya seperti saat selesai bermain di luar ataupun di dalam kelas, 
peserta didik TK Islam El-Qalam dipandu untuk membereskan serta merapikan mainannya serta mengembalikan ke tempat semula, demikian juga ketika anakanak selesai makan, selesai sholat dan ketika selesai melakukan kegitan lainnya. Peserta didik TK Islam El-Qalam diajarkan mengelap meja bekas tumpahan air yang mereka pakai serta meletakkan botol minum dan tempat makanan di loker yang disediakan, mereka juga harus dilibatkan ketika guru mengatur meja dan kursi belajar dikelas. Menurut (Rasyid, 2012) bahwa keterlibatan ini penting untuk menanamkan rasa tanggung jawab dan rasa memiliki dikalangan peserta didik.

2. Implementasi Nilai Moral di TK Islam ElQalam Pamulang

Nilai-nilai moral adalah kemampuan anak untuk bersikap dan bertingah laku, islam telah mengajarkan nilai-nilai positif yang bermanfaat dalam kehidupan bermasyarakat, implementasi nilai moral pada peserta didik TK Islam El-Qalam melalui penanman nilai sopan, menghargai, dan peduli

a) Implementasi Nilai Sopan

Sebagaimana penjelasan dari guru kelompok B1 yang menjelaskan penanaman nilai sopan kepada peserta didik elqalam juga dilakukan melalui contoh yang baik dari guru seperti menundukkan badan sebagai ungkapan hormat saat berjalan di depan orang tua dan bertutur kata yang sopan dan lembut, tidak dengan suara tinggi apalagi membentak kepada orang tua dan guru, aktivitas yang dilakukan adalah guru memberikan contoh terlebih dahulu lalu anak-anak mengikutinya selain itu adanya pembelajaran sopan santun. Penanaman nilai sopan kepada peserta didik TK Islam El-Qalam Pamulang juga dilakukan melalui contoh yang diberikan pendidik pada peserta didik seperti berkata sopan, berbicara dengan suara lembut dan berteriak. Meminta bantuan ktika membutuhkannya dengan menggunakan kata tolong Terbiasa mengucapkan kata "terima kasih" saat mereka meminta sesuatu atau dibantu, pada penelitian ini peneliti dengan merujuk pada hasil observasi dan hasil wawancara, dan dokumen tertulis yang didapat dari pengelola TK Islam El-Qalam Pamulang, peneliti dapat menyimpulkan bahwasanya pendidikan berbasis fitrah maniusi yang terplementasikan pada nila-nilai kesopanan yang tercermin dalam pembiasaanpembiasaan sangat kental terasa pada pendidikan yang ada di TK Islam El-Qalam Pamulang.

b) Implementasi Nilai Menghargai

Menghargai adalah sikap, dan tindakan yang mendorong dirinya untuk menghasilkan sesuatu yang berguna bagi masyarakat, dan mengakui serta menghormati apa yang dilakukan orang lain, Dalam implementasi nilai menghargai TK Islam El-Qalam Pamulang menerapkan beberapa sikap yang ditanamkan pada peserta didik dintaranya adalah berperilaku hormat kepada yang lebih tua, meminta maaf ketika berbuat salah, memuji hasil karya orang lain, berterima kasih apabila sudah dibantu. Sebagaimana penjelasan dari pembimbing kelompok B1 yang menjelaskan bahwa implementasi nilai menghargai pada sesama merupakan salah satu tujuan pendidikan yang ada di visi misi pendidikan TK Islam El-Qalam Pamulang, Pelatihan menuju itu ada pada serangkaian pembiasaan dalam pembelajaran yang dilaksanakan setiap hari, dengan contoh-contoh sederhana yaitu meminta maaf bila bersalah, meminta izin apabila akan keluar kelas, meminta izin apabila menginginkan makanan milik teman yang lain, dan masih banyak lagi contoh-contoh sederhana yang membuat anak menghargai orang lain.

Anak dilatih untuk meminta maaf kepada teman. Biasanya pada saat bermain ada anak yang rebutan mainan sehingga terkadang anak yang menangis atau bertengkar, dan salah satu dari mereka tidak ada yang mau meminta maaf. Pada saat itu kita minta anak untuk saling bersalaman dan kita memberikan contoh perkataan cara meminta maaf yang baik kepada teman, dengan mengumpulkan dari berbagai sumber data melalui wawancara dan observasi maka peneliti dapat disimpulkan bahwa pendidikan berbasis fitrah manusia di TK Islam El-Qalam Pamulang sudah mengimplementasikannya melalui pengembangan nilai menghargai kepada sesama manusia, menghargai yang lebih tua, menghargai teman dan menghargai sesama. Dengan harapan penanaman nilai-nilai terpuji dapat mem- 
bentuk akhlak yang mulia seperti yang dicontohkan Rasulullah SAW.

c) Nilai Peduli

Implementasi nilai peduli kepada peserta didik TK Islam El-Qalam juga selalu dilakukan baik di sekolah adalah kemampuan mengenali atau merasakan keadaan yang tengah dialami orang lain, peduli merupakan sisi emosional dari pengambilan perspektif. Fakta bahwa anak-anak dapat berbeda-beda dalam menunjukkan rasa peduli menunjukkan bahwa orang tua dan guru harus bekerja lebih keras untuk menghadapi anak-anak tertentu dan membantu untuk bisa memahami dan bersikap peduli terhadap perasaan orang lain, tugas orang tua dan guru adalah membangun peduli yang digeneralisasikan, peduli yang mampu melihat sampai ke balik perbedaan dan merespon pada sesama manusia. Penjelasan yang disampaikan oleh pendamping kelas kelompok B1 yang menyatakan bahwa biasanya kalau ada teman yang sakit, kita mengajak anak-anak untuk ikut serta menjenguknya, jika rumahnya itu dekat dengan sekolah, akan tetapi jika rumahnya itu jauh kita hanya mengajak beberapa anak atau hanya bu guru saja yang menjenguknya. Analisis Kesesuaian implementasi Nilai Agama dan Moral Di TK Islam El-Qalam dengan Pendidikan Berbasis Fitrah Manusia.

Pada penelitian ini peneliti menemukan beberapa fakta yang diperoleh dilapangan dari hasil observasi, wawancara dan dokumentasi mengenai implementasi pendidikan berbasis fitrah manusi dalam penanaman nilai agama moral pada anak usia dini di TK Islam El-Qalam Tahun pelajaran 2019/2020 diatas, maka dapat di-interpretasikan bahwa adanya kesesuaian antara pendidikan berbasis fitrah manusia dengan penanman Nilai Agama dan Moral yang terdapat pada beberapa teori yang sudah dikemukakan. Adapun tujuan yang hendak dicapai pada implementasi pendidikan berbasis Fitrah manusia dalam penanaman nilai agama moral pada anak usia dini melalui keteladanan, pembiasaan dan mudawwamah yaitu adanya perubahan pada diri siswa untuk menjadi manusia yang baik dan benar dalam ber-perilaku sebagai umat tuhan, anak, keluarga dan masyarakat. Temuan fakta menunjukkan, menurut Sjarkawi, pendidikan moral bertujuan membina terbentuknya perilaku moral yang baik bagi setiap orang. Artinya pendidikan moral bukan sekedar memahami tentang aturan benar dan salah atau mengetahui tentang ketentuan baik dan buruk, tetapi harus benar-benar meningkatkan perilaku moral seseorang, Untuk menanamkan nilai agama dan moral pada anak PAUD khususnya di TK Islam ElQalam terdapat beberapa hal yang menjadi pendukung dan penghambat. Adapun hal-hal yang menjadi penghambat dan yang mempengaruhi nilai agama moral anak diantaranya pembawaan diri anak yang kurang baik, lingkungan yang kurang mendukung, latar belakang orang tua yang berbeda-beda, waktu pembelajaran disekolah yang sebentar dan tidak ada pengulangan dari orang tua dirumah.

\section{SIMPULAN DAN SARAN}

\section{A. Simpulan}

Berdasarkan pemaparan pada penelitian implementasi pendidikan berbasis fitrah manusia dalam penanaman nilai agama dan moral pada anak usia dini di Tk Islam ElQalam Pamulang ini dapat disimpulkan bahwa implemetasi nilai agama dan moral pada peserta didik TK Islam El-Qalam Pamulang sudah dilakukan pada setiap kegiatan dari awal pembelajaran. Pembelajaran inti sampai akhir pembelajaran yang dilakukan dengan metode keteladanan, pembiasaan, pengulangan, pelatihan dan motivasi, pendidkan berbasis fitrah manusia menurut memiliki banyak dimensi, dan dimensi yang terpenting adalah fitrah agama, fitrah intelek, fitrah sosial, fitrah seni dan fitrah kemajuan, adanya kesesuaian fakta temuan peneliti pada implementasi nilai agama dan moral di TK Islam El-Qalam Pamulang yang sesuai dengan teori yang ada bahwa pengembangan karakter pada anak usia dini (AUD) lebih menekankan pada metode keteladanan, pembiasaan, pengulangan, pelatihan, dan motivasi. Indikator keberhasilan pengembangan karakter anak usia dini dapat diketahui dari perilaku sehari-hari yang tampak pada setiap aktivitas yakni kesadaran, kejujuran, keikhlasan, kesederhanaan, kemandirian, kepedulian, kebebasan dalam bertindak, kecermatan/ ketelitian dan komitmen, hal ini me-nunjukkan adanya kesesuaian antara pepenanman nilai agama dan moral dengan pendidikan berbasis fitah manusia dibatasi pada fitrah agama dan 
fitrah sosial manusia, dilihat dari nilai-nilai yang terkandung pada keduanya.

\section{B. Saran}

Pembahasan terkait penelitian kajian terhadap implementasi pendidikan berbasis fitrah manusia dalam penanaman nilai agama dan moral pada anak usia dini di Tk Islam ElQalam Pamulang dalam penelitian ini masih sangat terbatas dan membutuhkan banyak masukan. Saran untuk penulis selanjutnya adalah mengkaji lebih dalam dan secara komprehensif terkait kajian terhadap implementasi pendidikan berbasis fitrah manusia dalam penanaman nilai agama dan moral pada anak usia dini di Tk Islam El-Qalam Pamulang.

\section{DAFTAR RUJUKAN}

Arifudin, O. (2021). Konsep Dasar Pendidikan Anak Usia Dini. Bandung: Widina Bhakti Persada Bandung.

Arifudin, O. (2020). Psikologi Pendidikan (Tinjauan Teori Dan Praktis). Bandung: Widina Bhakti Persada.

Arifudin, 0. (2018). Pengaruh Pelatihan Dan Motivasi Terhadap Produktivitas Kerja Tenaga Kependidikan STIT Rakeyan Santang Karawang. MEA (Manajemen, Ekonomi, \& Akuntansi), 2(3), 209-218.

Ayuningsih. (2012). Psikologi Perkembangan Anak. Yogyakarta: Pustaka La-rasati.

Bahri, A. S. (2021). Pengantar Penelitian Pendidikan (Sebuah Tinjauan Teori dan Praktis). Bandung: Widina Bhakti Persada.

Hanafiah, H. (2021). Pelatihan Software Mendeley Dalam Peningkatan Kualitas Artikel Ilmiah Bagi Mahasiswa. Jurnal Karya Abdi Masyarakat, 5(2), 213-220.

Helmawati. (2014). Pendidikan Keluarga. Bandung: PT. Remaja Rosdakarya.

Jalaluddin. (1997). Psikologi Agama. Jakarta: Raja Grafindo Persada.

Mansur. (2007). Pendidikan Anak Usia Dini dalam Islam. Yogyakarta: Pustaka Pelajar.
Mujib. (1999). Fitrah dan Kepribadian Islam, Sebuah pendekatan Psikologis. Jakarta: Darul Falah.

Na'im, Z. (2021). Manajemen Pendidikan Islam. Bandung : Widina Bhakti Persada.

Nasser, A. A. (2021). Sistem Penerimaan Siswa Baru Berbasis Web Dalam Meningkatkan Mutu Siswa Di Era Pandemi. Biormatika: Jurnal Ilmiah Fakultas Keguruan Dan Ilmu Pendidikan, 7(1), 100-109.

Rahayu, Y. N. (2020). Program Linier (Teori Dan Aplikasi). Bandung : Widina Bhakti Persada.

Rasyid. (2012). Asesmen Perkembangan Anak Usia Dini. Yogyakarta:Gama Media.

Supriani, Y. (2022). Peran Manajemen Kepemimpinan dalam Pengelolaan Lembaga Pendidikan Islam. JIIP-Jurnal Ilmiah Ilmu Pendidikan, 5(1), 332-338.

Suyadi. (2020). Psikologi Belajar Anak Usia Dini. Yogyakarta : PT Pustaka Aadani.

Syaodih. (2009). Landasan Psikologi dan Proses Pendidikan. Bandung: PT Remaja Rosdakarya.

Tanjung, R. (2020). Pengaruh Penilaian Diri Dan Efikasi Diri Terhadap Kepuasan Kerja Serta Implikasinya Terhadap Kinerja Guru. Jurnal Ilmiah MEA (Manajemen, Ekonomi, Dan Akuntansi), 4(1), 380-391.

Tanjung, R. (2022). Manajemen Penyelenggaraan Pendidikan Inklusi pada Lembaga Pendidikan Islam. JIIP-Jurnal Ilmiah Ilmu Pendidikan, 5(1), 339-348.

Ulfah, U. (2022). Kepemimpinan Pendidikan di Era Disrupsi. JIIP-Jurnal Ilmiah Ilmu Pendidikan, 5(1), 153-161.

Ulwan. (1992). Pendidikan Anak Menurut Islam Kaidah-kaidah Dasar. Bandung: Remaja Rosdakarya. 